\title{
Editorial for the Special Issue on Computational Quantum Physics and Chemistry of Nanomaterials
}

\author{
Mojmír Šob ${ }^{1,2,3}$ \\ 1 Department of Chemistry, Faculty of Science, Masaryk University, Kotlářská 2, \\ CZ-611 37 Brno, Czech Republic; sob@chemi.muni.cz or mojmir@ipm.cz or mojmir.sob@ceitec.muni.cz \\ 2 Institute of Physics of Materials, v.v.i., Czech Academy of Sciences, Žižkova 22, \\ CZ-616 62 Brno, Czech Republic \\ 3 Central European Institute of Technology, CEITEC MU, Masaryk University, Kamenice 5, \\ CZ-625 00 Brno, Czech Republic
}

Received: 4 November 2020; Accepted: 27 November 2020; Published: 30 November 2020

Nanomaterials have become increasingly important both in basic research and in applications. Some properties may be understood only at the level of the quantum mechanical study of these materials. The purpose of this Special Issue is to advance our fundamental understanding of the structure and technologically important properties of nanomaterials with the help of computational quantum solid-state physics and chemistry. There is no doubt that quantum mechanical approaches are indispensable in comprehensive studies of nanomaterials and will be increasingly crucial in the future. Of course, this field is too extensive and too diverse to be described in a single volume. Nevertheless, this Special Issue provides at least a partial snapshot of the state of the art of computational quantum mechanical studies of nanomaterials and covers some recent advances and problems.

The scope of the articles included in this Special Issue is quite diverse, including adsorption of gas molecules on nanoclusters [1], domain structure of magnetically doped topological insulators [2], properties of dye-sensitized solar cells [3], energetics of silver decahedron nanoparticles [4], the effect of the size and shape on the surface energy of Au nanoparticles [5], critical size of ferroelectric SnTe low-dimensional nanostructures [6], the effect of vacancies on grain boundary segregation in ferromagnetic nickel [7], generalized stacking-fault energy in selected high-entropy alloys [8], phase transition of cesium lead halide perovskite nanocrystals [9], structural evolution of AlN nanoclusters [10] and the shock sensitivity of selected energetic materials [11].

In all these cases, application of the quantum methods was indispensable to determine how various features of atomic configuration of these materials are reflected in their properties and experimentally ascertained quantities.

In summary, this Special Issue of Nanomaterials collects a series of original research articles providing new insight into the application of computational quantum physics and chemistry in research on nanomaterials. It illustrates the extension and diversity of the field and indicates some future directions. I am confident that this Special Issue will provide the reader with an overall view of the latest prospects in this fast evolving and cross-disciplinary field.

Funding: M. Š. acknowledges the financial support from the Ministry of Education, Youth and Sports of the Czech Republic in the range of the Project CEITEC 2020 (Project No. LQ1601) and from the Institute of Physics of Materials of the Czech Academy of Sciences in Brno, Czech Republic.

Acknowledgments: The Guest Editor thanks all the authors for submitting their work to this Special Issue and for contributing to its successful completion. A special thank you belongs to all the reviewers participating in the peer-review process of the submitted manuscripts for enhancing their quality and impact. I am also grateful to Ms. Tracy Jin and the editorial assistants who made the entire Special Issue creation a smooth and efficient process.

Conflicts of Interest: The author declares no conflict of interest. 


\section{References}

1. Liang, Q.; Nie, X.; Du, W.; Zhang, P.; Wan, L.; Ahuja, R.; Ping, J.; Qian, Z. First-Principles Exploration of Hazardous Gas Molecule Adsorption on Pure and Modified $\mathrm{Al}_{60} \mathrm{~N}_{60}$ Nanoclusters. Nanomaterials 2020, 10, 2156. [CrossRef] [PubMed]

2. Šebesta, J.; Carva, K.; Kriegner, D.; Honolka, J. Twin Domain Structure in Magnetically Doped $\mathrm{Bi}_{2} \mathrm{Se}_{3}$ Topological Insulator. Nanomaterials 2020, 10, 2059. [CrossRef] [PubMed]

3. Rashid, M.A.M.; Hayati, D.; Kwak, K.; Hong, J. Theoretical Investigation of Azobenzene-Based Photochromic Dyes for Dye-Sensitized Solar Cells. Nanomaterials 2020, 10, 914. [CrossRef]

4. Polsterová, S.; Friák, M.; Všianská, M.; Šob, M. Quantum-Mechanical Assessment of the Energetics of Silver Decahedron Nanoparticles. Nanomaterials 2020, 10, 767. [CrossRef] [PubMed]

5. Holec, D.; Dumitraschkewitz, P.; Vollath, D.; Fischer, F.D. Surface Energy of Au Nanoparticles Depending on Their Size and Shape. Nanomaterials 2020, 10, 484. [CrossRef] [PubMed]

6. Shimada, T.; Minaguro, K.; Xu, T.; Wang, J.; Kitamura, T. Ab Initio Study of Ferroelectric Critical Size of SnTe Low-Dimensional Nanostructures. Nanomaterials 2020, 10, 732. [CrossRef]

7. Mazalová, M.; Všianská, M.; Pavlů, J.; Šob, M. The Effect of Vacancies on Grain Boundary Segregation in Ferromagnetic $f_{c c}$ Ni. Nanomaterials 2020, 10, 691. [CrossRef]

8. Sun, X.; Zhang, H.; Li, W.; Ding, X.; Wang, Y.; Vitos, L. Generalized Stacking Fault Energy of Al-Doped CrMnFeCoNi High-Entropy Alloy. Nanomaterials 2020, 10, 59. [CrossRef]

9. Yun, R.; Luo, L.; He, J.; Wang, J.; Li, X.; Zhao, W.; Nie, Z.; Lin, Z. Mixed-Solvent Polarity-Assisted Phase Transition of Cesium Lead Halide Perovskite Nanocrystals with Improved Stability at Room Temperature. Nanomaterials 2019, 9, 1537. [CrossRef]

10. Nie, X.; Qian, Z.; Du, W.; Lu, Z.; Li, H.; Ahuja, R.; Liu, X. Structural Evolution of AlN Nanoclusters and the Elemental Chemisorption Characteristics: Atomistic Insight. Nanomaterials 2019, 9, 1420. [CrossRef] [PubMed]

11. Zhang, L.; Yu, Y.; Xiang, M. A Study of the Shock Sensitivity of Energetic Single Crystals by Large-Scale Ab Initio Molecular Dynamics Simulations. Nanomaterials 2019, 9, 1251. [CrossRef]

Publisher's Note: MDPI stays neutral with regard to jurisdictional claims in published maps and institutional affiliations.

(C) 2020 by the author. Licensee MDPI, Basel, Switzerland. This article is an open access article distributed under the terms and conditions of the Creative Commons Attribution (CC BY) license (http://creativecommons.org/licenses/by/4.0/). 